\title{
Federal and regional budget expenditures on environmental adaptation (using the example of Tyumen region, Russia)
}

\author{
Elena Chernykh ${ }^{1, *}$, Alexander Sizov ${ }^{2}$ \\ ${ }^{1}$ Industrial University of Tyumen, Tyumen, Russia \\ ${ }^{2}$ Moscow State University of Geodesy and Cartography, Moscow, Russia
}

\begin{abstract}
The state policy of the Tyumen region in the field of environmental protection and development of mineral resource base is aimed at increasing the level of environmental safety and preservation of natural systems, at ensuring rational land use and reproduction of natural resource potential of the territory.
\end{abstract}

\section{Introduction}

Priorities of the Tyumen region policy in the sphere of environmental protection and development of mineral resource base focused on:

- preserving the environment and reducing the negative impact, including by stimulating green growth of the economy and introducing efficient innovative technologies;

- restoration of disturbed natural ecosystems;

- formation of an effective management system in the field of environmental protection and ensuring environmental safety, including improving the efficiency of state environmental supervision by public authorities of the Tyumen region on the basis of an assessment of environmental risks, and provision of regional environmental impact assessment;

- implementation of projects for elimination of accumulated environmental damage, environmental rehabilitation of territories and the safe waste management;

- maintaining the Red Book of the Tyumen region, as well as the implementation of the strategy for the conservation of flora and fauna listed in the Red Book of the Tyumen region;

- ensuring sustainable operation and development of a system of specially protected natural areas of regional importance in order to preserve landscape and biological diversity;

- ensuring the reproduction and efficient use of the mineral resources base of common minerals and groundwater in the execution of powers of the Tyumen Region and

\footnotetext{
* Corresponding author: chernyheg@tyuiu.ru
} 
delegated powers of the Russian Federation to meet the needs of the economy and social sphere;

- development of the state system of environmental monitoring.

2017 has been declared the year of ecology in the Tyumen region and in Russia as a whole.

The main results and amounts of financing of the conducted activities are characterized by a significant involvement of the Tyumen government in addressing environmental issues (Table 1).

Table 1. Results of the Year of Ecology in the Tyumen region.

\begin{tabular}{|c|c|c|c|}
\hline No. & Name of event & $\begin{array}{c}\text { Volumes and } \\
\text { sources of funding }\end{array}$ & $\begin{array}{c}\text { The results of the implementation } \\
\text { of measures }\end{array}$ \\
\hline 1. & $\begin{array}{l}\text { Construction of a 4-waste } \\
\text { treatment plants in the city } \\
\text { of Tyumen, Yalutorovsk, } \\
\text { Ishim, Tobolsk }\end{array}$ & $\begin{array}{l}\text { Investment funds - } \\
1.5 \text { billion rubles }\end{array}$ & $\begin{array}{l}\text { Creation and operation of utility } \\
\text { infrastructure system - facilities } \\
\text { used for processing, recycling, } \\
\text { disinfection and disposal of } \\
\text { municipal solid waste in the } \\
\text { Tyumen region. } \\
\text { After reaching full capacity of all } \\
4 \text { plants, the proportion of waste } \\
\text { sent for disposal will be about } \\
20 \% \text { of all generated waste in the } \\
\text { Tyumen region }\end{array}$ \\
\hline 2. & $\begin{array}{l}\text { Construction of the electric } \\
\text { gas turbine station at the } \\
\text { South Nyurymsky oil field }\end{array}$ & $\begin{array}{l}\text { Funds of } \\
\text { JSC "Surgut } \\
\text { Neftegaz" - } \\
2.1 \text { billion rubles }\end{array}$ & $\begin{array}{l}\text { Increase in utilization of } \\
\text { associated gas up to } 98 \% \text {. } \\
\text { Decrease in the gross emission of } \\
\text { pollutants into the air in } 2017-2 \\
\text { thousand tons, in the future - up } \\
\text { to } 10 \text { thousand tons annually }\end{array}$ \\
\hline 3. & $\begin{array}{l}\text { Development and } \\
\text { implementation of a } \\
\text { system for collecting } \\
\text { mercury-containing waste, } \\
\text { spent sources of low } \\
\text { current (batteries) from the } \\
\text { population }\end{array}$ & $\begin{array}{l}\text { Without raising } \\
\text { funds }\end{array}$ & $\begin{array}{l}\text { Formation of a system of proper } \\
\text { treatment of mercury-containing } \\
\text { wastes }\end{array}$ \\
\hline 4. & $\begin{array}{l}\text { Conducting state registry } \\
\text { of objects that have a } \\
\text { negative impact on the } \\
\text { environment }\end{array}$ & $\begin{array}{l}\text { Without raising } \\
\text { funds }\end{array}$ & $\begin{array}{l}\text { Creation of the register of objects } \\
\text { that have a negative impact on the } \\
\text { environment in the Tyumen } \\
\text { region }\end{array}$ \\
\hline 5. & $\begin{array}{l}\text { Reforestation in the } \\
\text { Tyumen region (planting } \\
\text { forest crops on an area of } \\
\text { about } 3.5 \text { thousand } \mathrm{Ha} \text { ) }\end{array}$ & $\begin{array}{l}\text { Federal funds } * * \\
23.4 \text { million rubles }\end{array}$ & \multirow{2}{*}{$\begin{array}{l}\text { The timely and full recovery of } \\
\text { cuttings, burnt and dead forest } \\
\text { stands, other areas of silvicultural } \\
\text { fund, as well as clearcut areas } \\
\text { with economic-valuable tree } \\
\text { species, increasing the } \\
\text { productivity of forests, improving } \\
\text { the species composition. } \\
\text { Reduction of reforestation fund. }\end{array}$} \\
\hline 6. & $\begin{array}{l}\text { Promoting natural } \\
\text { reforestation (on an area of } \\
\text { about } 5 \text { thousand } \mathrm{Ha} \text { ) }\end{array}$ & $\begin{array}{l}\text { Federal funds ** } \\
3.5 \text { million rubles }\end{array}$ & \\
\hline 7. & $\begin{array}{l}\text { Taking measures to } \\
\text { prevent illegal timber } \\
\text { trafficking }\end{array}$ & $\begin{array}{l}\text { Without raising } \\
\text { funds }\end{array}$ & $\begin{array}{l}\text { Detection and suppression of } \\
\text { illegal timber trafficking, illegal } \\
\text { logging of forest stands }\end{array}$ \\
\hline 8. & $\begin{array}{l}\text { Elimination of } \\
\text { accumulated }\end{array}$ & $\begin{array}{l}\text { Regional budget } \\
\text { funds - }\end{array}$ & $\begin{array}{l}\text { Elimination of accumulated } \\
\text { environmental } \\
\text { damage from }\end{array}$ \\
\hline
\end{tabular}




\begin{tabular}{|l|l|l|l|}
\hline & $\begin{array}{l}\text { environmental damage } \\
\text { through reclamation or } \\
\text { elimination of } \\
\text { unauthorized dumps }\end{array}$ & RUB 18,252,000. & $\begin{array}{l}\text { previous economic activities. } \\
\text { Elimination of pollution sources. }\end{array}$ \\
\hline
\end{tabular}

\section{Study areas and analyses}

In 2018 the state program of the Tyumen region "Subsoil Use and Environmental Protection" was approved by the decision of the Government of the Tyumen region No. 504-p from December 14, 2018.

The purpose of the program:

- $\quad$ Reducing the negative impact of economic activities on the environment

- Conservation of biological and landscape diversity

- Development and management of mineral resources base

- Protection of the population and territories from the negative impact of water and protection of water bodies

Dates of the program: 2019-2025 years.

Volumes and sources of funding for the program:

Total for 2019-2025 at the expense of the regional and federal budgets - 4,003,971.546 thousand rubles, including by year:

For a further understanding of the issue of financing the federal budget allocated for the adaptation of the environment for the development of territories, we will analyze two factors and perform a non-linear regression analysis:

Factor 1: current (operational) costs of environmental protection in the Russian Federation (Table 2);

Factor 2: investment in fixed assets aimed at environmental protection and rational use of natural resources in the Russian Federation (Table 3).

Table 2. The current (operational) costs of environmental protection in the Russian Federation (In actual prices, millions of rubles).

\begin{tabular}{|c|c|c|c|c|c|c|c|c|c|c|}
\hline \multirow[b]{2}{*}{ 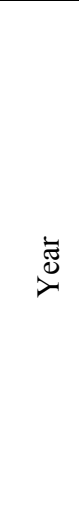 } & \multirow[b]{2}{*}{ 吾 } & \multicolumn{9}{|c|}{ including: } \\
\hline & & 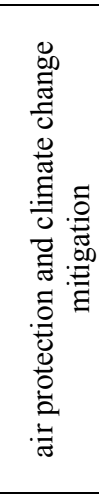 & 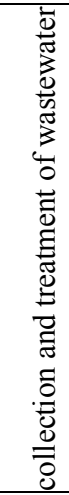 & 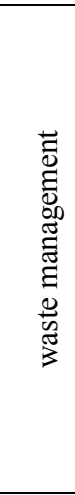 & 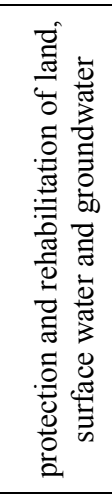 & 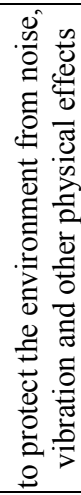 & 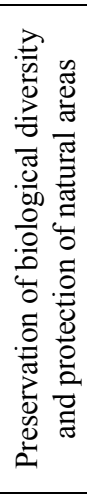 & 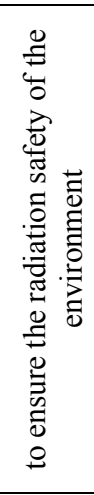 & 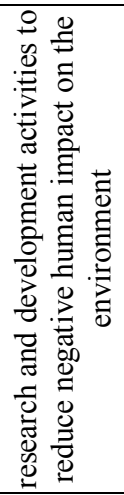 & 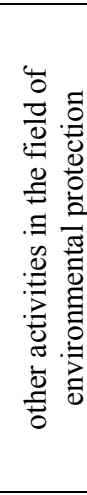 \\
\hline 2012 & $\begin{array}{l}239 \\
170\end{array}$ & 47062 & $\begin{array}{l}121 \\
332\end{array}$ & $\begin{array}{c}457 \\
98\end{array}$ & 13701 & 262 & 534 & 4795 & 460 & 5225 \\
\hline 2013 & $\begin{array}{l}254 \\
377\end{array}$ & 44800 & $\begin{array}{l}132 \\
818\end{array}$ & $\begin{array}{c}504 \\
02\end{array}$ & 15337 & 273 & 314 & 5342 & 1022 & 4069 \\
\hline 2014 & $\begin{array}{l}269 \\
838\end{array}$ & 50920 & $\begin{array}{l}136 \\
468\end{array}$ & $\begin{array}{c}557 \\
02\end{array}$ & 15266 & 308 & 350 & 6088 & 937 & 3799 \\
\hline 2015 & $\begin{array}{l}292 \\
074\end{array}$ & 58250 & $\begin{array}{l}145 \\
147\end{array}$ & $\begin{array}{c}602 \\
56\end{array}$ & 16660 & 289 & 336 & 5459 & 582 & 5096 \\
\hline
\end{tabular}




\begin{tabular}{|l|c|c|c|c|c|c|c|c|c|c|}
\hline $\mathbf{2 0 1 6}$ & $\begin{array}{l}306 \\
534\end{array}$ & 56851 & $\begin{array}{c}154 \\
313\end{array}$ & $\begin{array}{c}635 \\
80\end{array}$ & 19526 & 357 & 396 & 5843 & 647 & 5022 \\
\hline $\mathbf{2 0 1 7}$ & $\begin{array}{l}320 \\
947\end{array}$ & 56906 & $\begin{array}{c}163 \\
261\end{array}$ & $\begin{array}{c}700 \\
41\end{array}$ & 15452 & 289 & 422 & 6328 & 464 & 7783 \\
\hline $\mathbf{2 0 1 8}$ & $\begin{array}{c}345 \\
464\end{array}$ & 61075 & $\begin{array}{c}173 \\
688\end{array}$ & $\begin{array}{c}798 \\
85\end{array}$ & 15347 & 381 & 514 & 7728 & 205 & 6641 \\
\hline
\end{tabular}

Table 3. Investment in fixed assets aimed at environmental protection and rational use of natural resources in Russia (million rubles in current prices).

\begin{tabular}{|l|c|c|c|c|c|c|c|}
\hline $\begin{array}{c}\text { Investment in fixed } \\
\text { assets aimed at } \\
\text { environmental protection }\end{array}$ & \multicolumn{7}{|c|}{ Observation period, year } \\
\hline & 2012 & 2013 & 2014 & 2015 & 2016 & 2017 & 2018 \\
\hline Total & 116543 & 123807 & 158636 & 151788 & 139677 & 154042 & 157651 \\
\hline $\begin{array}{l}\text { including the protection } \\
\text { of: }\end{array}$ & & & & & & & \\
\hline air & 34626 & 41196 & 55587 & 40120 & 40340 & 60199 & 65475 \\
\hline water resources & 52420 & 59505 & 76315 & 78962 & 67469 & 66496 & 62750 \\
\hline lands & 19888 & 13802 & 14540 & 15703 & 12228 & 10216 & 10011 \\
\hline
\end{tabular}

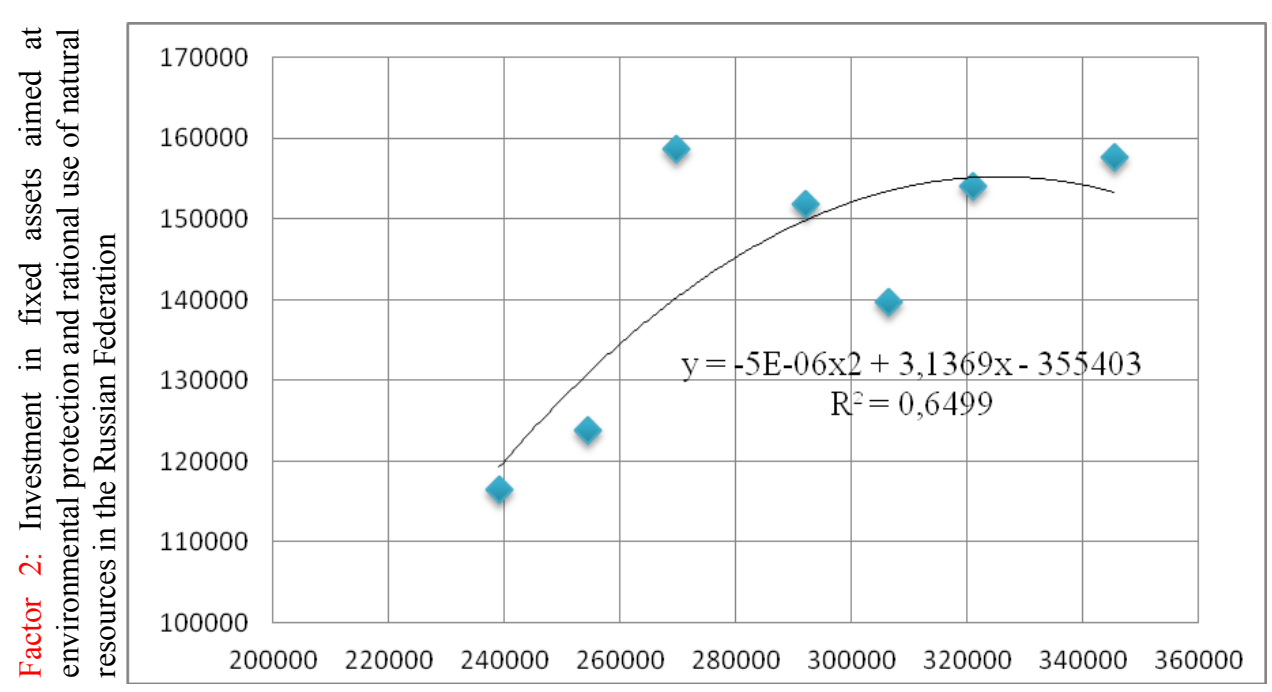

Factor1: Current (operational) costs of environmental protection in the Russian Federation

Fig. 1. Graph a polynomial regression model.

The coefficient of determination $\mathrm{R} 2=0.64$ showed that the estimated parameters of the model, i.e. the model itself, explain the dependence and changes of the studied parameter $\mathrm{Y}$, i.e. investment in fixed assets of the studied factor - X, - the current operating costs for environmental protection. We can say that this is an indicator of the quality of the model, and the higher it is, the better.

Thus, from the above presented model, we can conclude that the percentage of variation of the explained variable $y$ is taken into account in the model and is caused by the influence on it of the factors included in the model. 
Present and future costs of environmental protection and rational use of natural resources carried out at the expense of their own or borrowed funds of the company or the state budget directly depend on the amount of investments in fixed assets aimed at environmental protection and rational use of natural resources. The more investments are made today, the more obvious is the "cumulative effect" in the future, and as a result, it is possible to reduce the current (operational) costs of environmental protection.

Next, we analyze the dependence of the following factors in all municipal districts of the Tyumen region in the period from 2014 to 2017.

Factor 3: total amount of pollutants emitted by all stationary sources;

Factor 4: caught and neutralized pollutants emitted by all stationary sources.

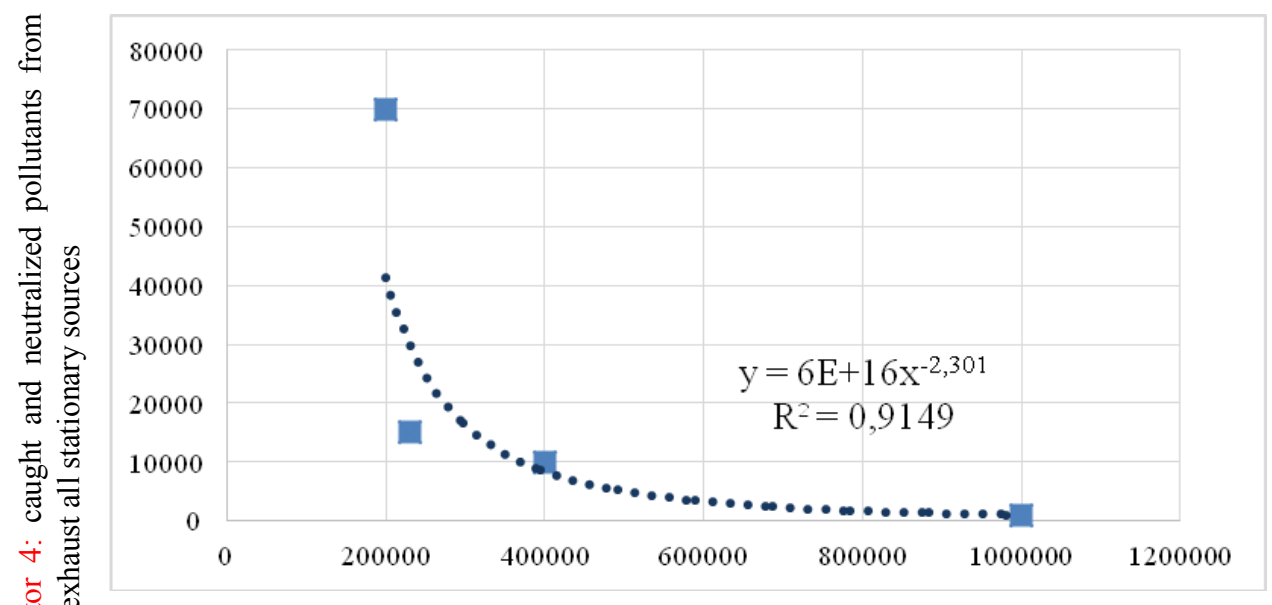

Factor 3: total amount of pollutants emitted by all stationary sources

Fig. 2. Graph of the power regression model.

The resulting model shows that the coefficient of determination is close to unity, thus the described model is qualitative. It can be concluded that the greater the emissions in the areas of the Tyumen region, the smaller their proportion is captured and neutralized annually.

At the final stage of the regression analysis, we establish the dependence of the following factors in all municipal districts of the Tyumen region for 2008-2018:

Factor 5: total expenses of the consolidated budget of the municipal district, thousand rubles

Factor 6: current (operational) costs of environmental protection (hereinafter EP), including payment for environmental protection services, thousand rubles 


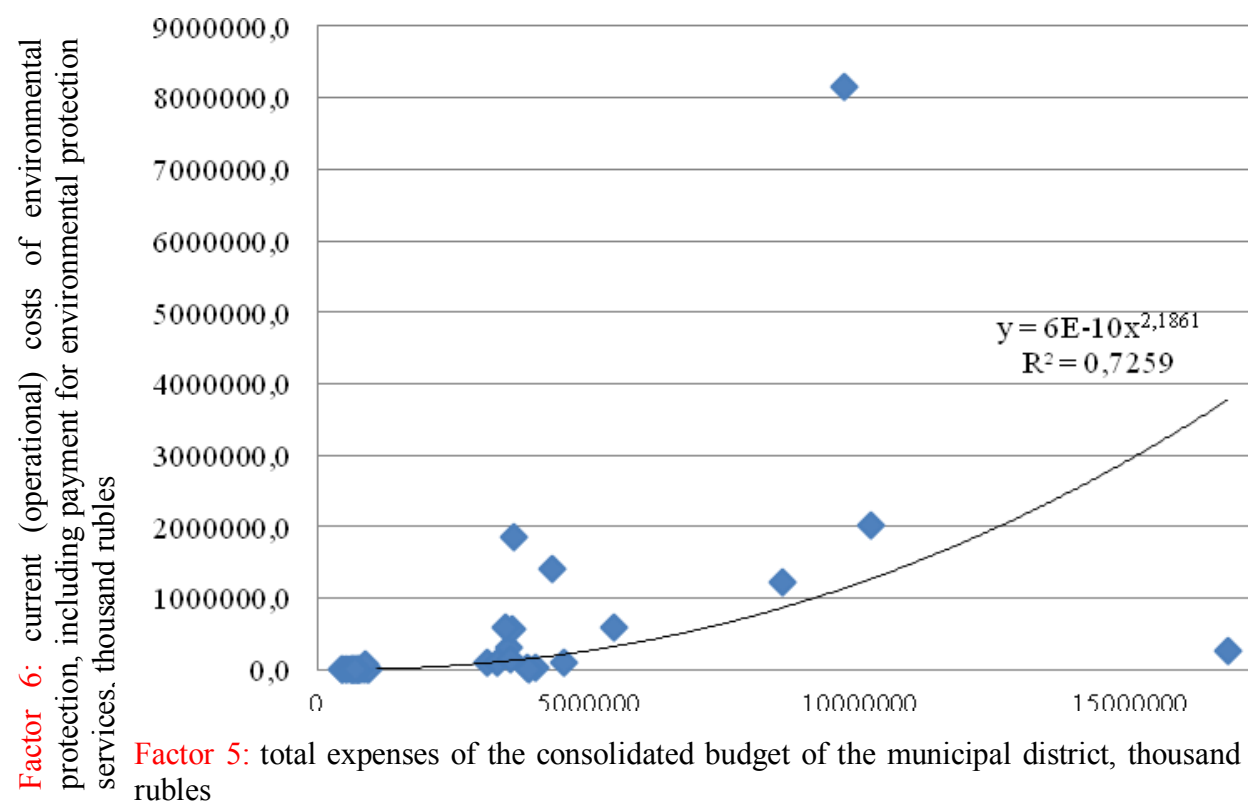

Fig. 3. Graph of the power regression model.

\section{Conclusion}

Analyzing the empirical data of the compared time series, when assessing the cause-andeffect relationship of their development, it is necessary to emphasize the following: with an increase in the expenditures of the consolidated budget of the municipal district (this is due to the pricing policy of economic entities that put inflation risks in the price of products, and the current tax system), the cost of environmental protection is increasing at a rate that is ahead of the growth of expenditures of the consolidated budget (Fig. 3). This means that significant contributions for current costs of environmental protection are possible only upon reaching a certain level of consolidated budget. In other words, it is possible to invest the remaining serious funds in environmental protection only after satisfying the vital needs of municipalities. This does not always have a favorable effect on the adaptation of environmental factors to the requirements of comfort and environmental safety of urbanized territories.

In this regard, due to the increasing intensity of the region's industrialization, a fundamental revision of the regional regulatory framework for calculating the contributions of economic entities for the restoration of environmental protection is required. Such an update of the regulatory framework in favor of environmental protection measures is a $21 \mathrm{st}$ century problem, universally solved by industrially developed countries. In Russia, this problem is being given superficial attention.

Thus, a brief study showed that the distribution of federal and regional budgetary funds, investments in fixed assets is quite significant, but it is not enough to solve the problems of environmental adaptation for the development of territories at the regional level.

\section{References}

1. Russian Federal Law "On the Federal Budget for 2017 and the planning period of 2018 
and 2019 years" N 415-FZ

2. Regions of Russia. Socio-economic indicators (Stat. Sat., Rosstat., Moscow, 2017)

3. A.I. Golovanov, Environmental engineering: a textbook for university students (Colossus, Moscow, 2008)

4. T.V. Ilyushin, Proceedings of the universities. Surveying and aerial photography $3,84-$ 95 (2013)

5. A.P. Sizov, State management accounting system for the management and development of territories of the Russian Federation (inventories, registers, registers): textbook for university students (Publishing house "KnoRus", Moscow, 2016)

6. A.P. Sizov, Information resources of the state real estate cadastre and terplanirovaniya in spatial development: Monograph ("Rusayns", Moscow, 2016)

7. A.P. Sizov, Environmental land bases in the mega-city: Monograph ("Rusayns", Moscow, 2015) 